\title{
Fire-protection of wooden structures by modification in a thin surface layer
}

\author{
Elena Pokrovskaya*
}

Moscow State University of Civil Engineering, Yaroslavskoe shosse, 26, Moscow, 129337, Russia

\begin{abstract}
The mechanism of fire protection of wood by the modification of a thin surface layer with organophosphorus compounds has been studied. The properties of the modified thin surface layer were studied by $\mathrm{X}$-ray spectral analysis, IR spectroscopy and differential thermal analysis. Promising wood modifiers have been identified and the conditions for effective fire protection of wooden structures with organophosphorus compounds in a thin surface layer have been determined.
\end{abstract}

\section{Foreword}

Wood is the material renewed by the nature. Use of designs and products from wood is relevant now.

Wood is an excellent natural composite, the main component of which is cellulose and lignin, which form a polymer complex bow; its preservation over time reflects the durability of the structure. The change in the content of bow components over time is shown in Figure1.

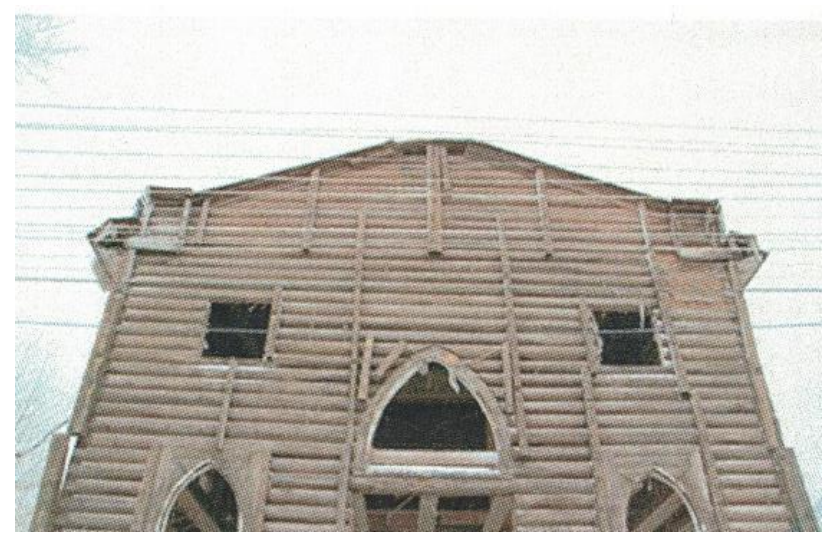

Fig. 2. The change in the content of bow components over time. Samples were taken from the interiors of monuments.

\footnotetext{
* Corresponding author: elenapokrovskaya@bk.com
} 
In the global practice of wooden house construction, multi-storey houses of wooden structures are currently being built. High-rise wooden buildings were built in Austria, Great Britain, Norway, and Canada. In Russia, multi-storey houses from wooden structures are designed as well. The issues of effective fire protection of wooden structures are relevant [1].

During the restoration and reconstruction, wooden structures are treated with flame retardants. With significant penetration into the wood during long-term use, the interaction of flame retardants with components of wood composite begins. This leads to destruction. SP 64.13.330.2017 particularly specifies the ma coefficient, which takes into account the change in wood strength during impregnation. It was found that when impregnating the wood of monuments, $\mathrm{ma}=0.9$, that is the strength in the impregnating layer is reduced by $10 \%$. Studying the effective fire protection of wooden structures with modification in a thin surface layer $(1-1.5 \mathrm{~mm})$ during their long-term use is a vital task.

\section{Materials and results}

As modifiers of the surface layer of wood the following chemical combinations are used: trichlorethyl phosphate (TCEP), trichlorpropyl phosphate (TCPP), dimethyl phosphite (DMP), diethyl phosphite (DEP), dibutyl phosphite (DBP), difenile phosphite (DFF), dipropyl phosphite (DPP), Hexachlorocyclotriphosphazatriene (HCCTP).

The degree of chemical modification of a thin surface layer was determined as follows. Modifiers not bound by chemical bonds to the substrate were removed by extracting the samples with aqueous acetone solutions (1:1) with constant stirring for 6 hours at $45^{\circ} \mathrm{C}$. The percentage of phosphorus was determined by the method [2]. The data is presented in Table 1.

The presence of chemical bonds of OPC with the wood substrate is confirmed by the Fourier IR spectroscopy, using the Magna-750 spectrometer from Nicolet (USA).

Table 1. The percentage of phosphorus in surface layer of wood.

\begin{tabular}{|l|l|l|l|}
\hline No. & Modifier & chemical formula & $\begin{array}{l}\text { phosphorus content } \\
\text { in the surface layer, } \\
\%\end{array}$ \\
\hline 1 & Trichlorethyl phosphate & $\left(\mathrm{C}_{2} \mathrm{H}_{4} \mathrm{ClO}\right)_{3} \mathrm{P}(\mathrm{O})$ & 0.97 \\
\hline 2 & Trichlorpropyl phosphate & $\left(\mathrm{C}_{3} \mathrm{H}_{8} \mathrm{ClO}\right)_{3} \mathrm{P}(\mathrm{O})$ & 0.77 \\
\hline 3 & dimethyl phosphite & $\left(\mathrm{CH}_{3} \mathrm{O}\right)_{2} \mathrm{P}(\mathrm{O}) \mathrm{H}$ & 3.87 \\
\hline 4 & diethyl phosphite & $\left(\mathrm{C}_{2} \mathrm{H}_{5} \mathrm{O}\right)_{2} \mathrm{P}(\mathrm{O}) \mathrm{H}$ & 3.57 \\
\hline 5 & dibutyl phosphite & $\left(\mathrm{C}_{4} \mathrm{H}_{9} \mathrm{O}\right)_{2} \mathrm{P}(\mathrm{O}) \mathrm{H}$ & 2.26 \\
\hline 6 & difenile phosphite & $\left(\mathrm{C}_{6} \mathrm{H}_{5} \mathrm{O}\right)_{2} \mathrm{P}(\mathrm{O}) \mathrm{H}$ & 2.05 \\
\hline 7 & dipropyl phosphite & $\left(\mathrm{C}_{3} \mathrm{H}_{7} \mathrm{O}\right)_{2} \mathrm{P}(\mathrm{O}) \mathrm{H}$ & 2.31 \\
\hline 8 & Hexachlorocyclotriphosphazatriene & $\mathrm{P}_{3} \mathrm{~N}_{3} \mathrm{Cl}{ }_{6}$ & 0.36 \\
\hline
\end{tabular}

Figure 1 shows the change in the structure of the surface layer during the thermal decomposition of the original wood and the wood modified in a thin surface layer. The images were taken using the Quanta 200 scanning electron microscope. 


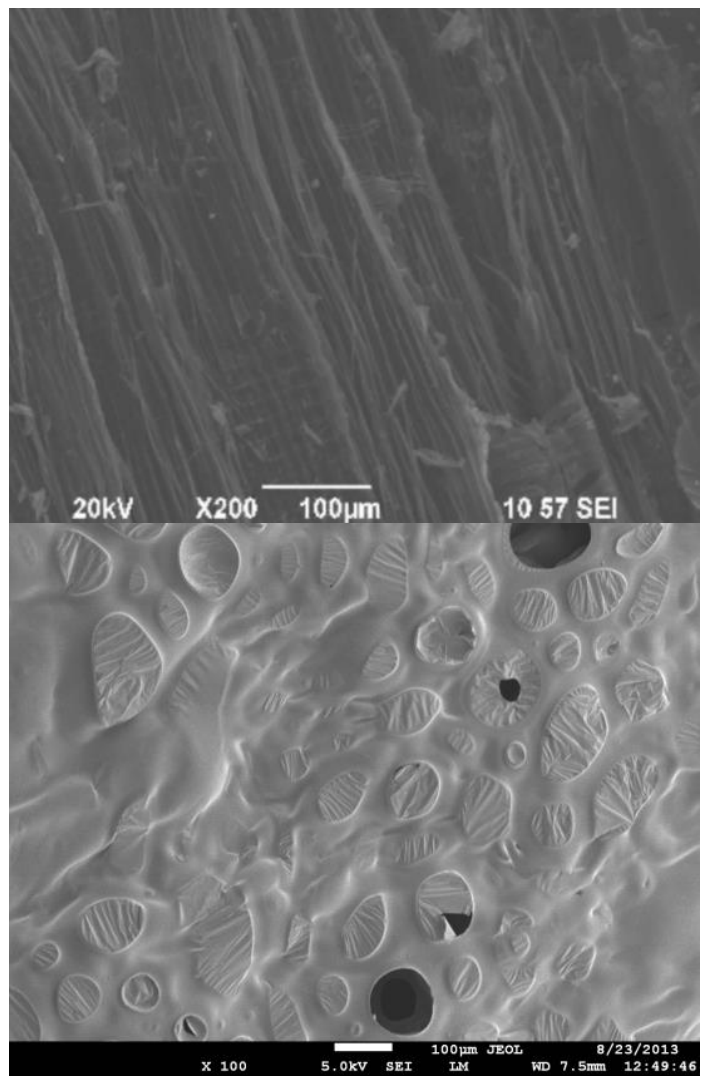

Fig. 1. The structure of carbonaceous layers after thermal decomposition of the original wood (at the top) and the wood modified with DMP in a thin surface layer under an electron microscope.

The parameters of thermal decomposition of the wood modified in a thin surface layer are presented in Table 2

Table 2. The parameters of thermal decomposition of the wood modified with OPC in a thin surface layer.

\begin{tabular}{|l|l|l|l|l|l|l|}
\hline No. & Modifier & $\mathrm{E}_{\text {act }}, \mathrm{kcal} / \mathrm{mol}$ & $\begin{array}{l}\text { Decrease in the } \\
\text { temperature of } \\
\text { the beginning } \\
\text { of thermal } \\
\text { decomposition, } \\
\Delta \mathrm{t}^{\circ} \mathrm{C}\end{array}$ & $\begin{array}{l}\text { Coke } \\
\text { extraction, } \%\end{array}$ & \multicolumn{2}{|l|}{$\begin{array}{l}\text { Phosphorus content in the } \\
\text { surface layer, \% }\end{array}$} \\
\cline { 4 - 8 } & & & $\begin{array}{l}\text { before thermal } \\
\text { decomposition }\end{array}$ & $\begin{array}{l}\text { afterthermal } \\
\text { decomposition }\end{array}$ \\
\hline 1 & TCEP & 41,9 & 25 & 36,3 & 0,97 & 0,43 \\
\hline 2 & TCPP & 49,8 & 24 & 30,6 & 0,77 & 0,26 \\
\hline 3 & DMP & 32,14 & 45 & 43,6 & 3,87 & 2,6 \\
\hline 5 & DEP & 33,0 & 35,3 & 46,3 & 3,51 & 4,7 \\
\hline Source wood & 47,4 & - & 18,1 & 0,36 & 0,13 \\
\hline
\end{tabular}

The fireproof efficiency group was determined in accordance with GOST R 532922009. The data on the fire resistance of the wood modified in thin surface layers are presented in Table 3 
Table 3. The data on the fire resistance of modified wood

\begin{tabular}{|c|c|c|c|c|c|c|}
\hline \multirow[t]{2}{*}{ Indicators } & \multicolumn{5}{|c|}{ Modifier } & \multirow{2}{*}{$\begin{array}{c}\text { Source } \\
\text { wood }\end{array}$} \\
\hline & TCEP & ТCPP & DMP & DEP & GCCTP & \\
\hline $\begin{array}{l}\text { Loss of } \\
\text { mass in } \\
\text { combustion } \\
\text { according to } \\
\text { GOST R } \\
53292-2009 \\
\end{array}$ & 11,6 & 16,7 & 6,9 & 8,6 & 16,6 & 89,0 \\
\hline $\begin{array}{l}\text { Fire- } \\
\text { retardant } \\
\text { effectiveness } \\
\text { group } \\
\text { according to } \\
\text { GOST R } \\
\text { 53292-2009 }\end{array}$ & II & II & I & I & II & III \\
\hline
\end{tabular}

\section{Discussions}

In the range of spectra of $1100-1300 \mathrm{~cm}^{-1}$, the intensities of $1234 \mathrm{~cm}^{-1}$ and $1124 \mathrm{~cm}^{-1}$ peaks of the wood modified with OPC-based solutions increase.

According to [4], this can be explained by the presence of the chemical bonds -C-O$\mathrm{P}(\mathrm{O})-\mathrm{O}-\mathrm{X}$.

The results of chemical analysis of modified wood surface layers suggest that the highest degree of modification is typical for phosphites - DMP and DEP $-3.87 \%$ and $3.57 \%$ in the treated surface, respectively

The value of the effective activation energy of the thermal decomposition process depends on the nature of modifier. Thermal decomposition peak value in the interval of up to $400{ }^{\circ} \mathrm{C}$ shifts to the region of lower temperatures. As a result, the effective activation energy of the process decreases, coke yield increases and coke structures contain larger amounts of chemically bound phosphorus. Of these modifiers, DMP and DEP are the most effective. The formation of heat-resistant phosphorylated coke layers leads to increased fire resistance, which is the aim of this paper.

As can be seen from Table 2, the samples of the wood modified with DMP and DEP in thin surface layers are characterized by the highest fire resistance efficiency. The obtained data supplement the results of an extensive research in terms of fire-resistance efficiency of wooden structures of various service life.

\section{Conclusion}

The research performed allows formulating the following conditions for effective fire protection of wood with organophosphorus compounds in thin layers:

-the modifier interacts with a substrate to form chemical bonds in thin layers;

-the effective activation energy of the wood thermal decomposition process decreases;

-in thermal decomposition, a thin surface layer turns into phosphorylated coke.

The obtained results make it possible to provide effective fire protection of wooden structures with a surface modification of both the newly constructed buildings and structures from wooden structures, and the restored wooden architecture monuments. Theoretical conclusions can form the basis for the development of fire retardants not only for wooden structures, but also for any hydroxylated coke-forming materials. 


\section{References}

1. X. Deglise, N. Brosse Research activity in lermab (wood research unit) an example: phytoremediation with trees and plants. International conference Renewable plant researches: chemistry, technology, medicine, 9, pp. 18-22, (2017)

2. A.V. Obolenskaya, A.A. Leonovich Laboratory works on chemistry of wood and cellulose, Ekologiya. (1991).

3. A.Kh. Kuptsov Fourier ranges of a combinational dispelling and infrared absorption of polymers, Fizmatlit, 656p, (2001)

4. V.M. Roitman, Engineering solutions for fire resistance assessment designed and renovated buildings, Fire safety and science, 382 p., (2001)

5. E.N. Pokrovskaya, Chemical and physical basis for increasing the longevity of wood, Moskow: ASV, 104 p., (2003)

6. E.N. Pokrovskaya, I.N. Chistov, Chemical Transformations of Wood under Long Contact with Soil, Forestry bulleten, 6, pp.88-93, (2009)

7. E.N. Pokrovskaya and Yu.K. Naganovskii, Durability of protective action of formulations for wood based on organoelenmental compounds, Building materials, $\mathbf{5}$, pp.52-54, (2004)

8. E.N. Pokrovskaya and I.V. Koteneva, Study of pulp and wood silylation kinetics, Forestry bulleten, 6, pp. 106-111, (2005)

9. B.A. Vorobiov, Flammability of polymeric materials, Stroizdat, 210 p. (1978)

10. B.B. Serkow, R.M. Aseeva and A.B. Sivenkow, Physical and chemical nature of combustion and fire hazard of wooden materials (part 2), Internet magazine "Technology tehnosfernoj security", 1, (2012)

11. A.N. Baratov, R.A. Andrianov, A.Ya. Korolchenko and V.A. Ushkov, Fire danger of building materials, Stroizdat, 380 p., (1988)

12. N.I. Vinnik, Modified wood: Stud. Handbook for universities, Forest industry, 160p., (1980)

13. V.A. Shamaev, N.C. Nikulina and I.N. Medvedev, Modification of wood. Monograph, Flinta publ. 448p., (2013)

14. A.A. Stenin, Improvement of properties of building materials from wood due to its surface modification, Construction - the Formation of the Environment of Life. Collection of Reports of XVI International Interuniversity Scientific-Practical Conference of Students, Undergraduates, Graduate Students and Young Scientists, MGSU Publ., pp. 553-59, (2008)

15. J.I. Goldstein and H. Yakowitz, Practical Scanning Electron Microscopy, New YorkLondon, Plenum Press, 582 p., (1975)

16. B.A. Kalin, Raster electron microscopy. Laboratory work, MIFI Publ., 56 p., (2008)

17. M.V. Bazilevskii Modern theory of chemical reactions in condensed phase, The advances of chemistry, 61, p.1185-1223, (1992) 